\title{
Migration crisis versus the control of the borderlines within the European Union
}

\section{Introduction}

Freedom of movement of people is one of the fundamental achievements of the European integration process and is the right of every single citizen of the European Union. It is one of the most visible instances of a notion which was the limelight for the founders of the European Community. As it is well noticed by S. M. Grochalski: "what may surprise is the fact that most of the citizens are aware of the fact that they have the right to move and take up a job freely in the area of the EU, however one may not be conscious that this entitlement stems directly from the regulation of movement and stay which as a citizen of the EU one may take advantage of any time with an apparent benefit for themselves" (Grochalski, 2015, p. 235). Everyday practice of "a life without the borders" in the united Europe has been recently challenged by the phenomenon of an increased migration process. In the situation of a lack of an adequate and immediate response of the European Union led to the increase in the sense of threat and danger in many EU countries (Pachocka, Visvizi, 2018). It became a susceptible floor for the activity of movements and parties which created on the basis of whatsoever the main point of their political agenda. The recommendations of the actions to be taken finally proposed by the EU Commission provoked arguments between the Commission and some of the EU member countries. It has not left the public opinion without a shade. In that kind of "political ambiance" there arose a problem of bringing back to life the cross-border control in the internal of the European Union.

\section{Freedom of movement of people within Schengen Treaty}

The outset of the process of searching the European solutions in the range of liberation and harmonizing the process of internal border-crossing in the countries belonging to the European Communities is to be seen first in 1974. At that very time the works on a plan leading to the passport community were carried out (Lesiewicz, 2016). A particular role in the action of coming to common community key in this domain was also played by the German-French consultations in Fontainebleu in June 1984 which ended up by a consensus in gradual suppression of control at the frontiers between these countries. Finally on $14^{\text {th }}$ of June 1985 in Schengen there was a pact signed on the matter of abrogating the control on the common borders (Convention Implementing the 
Schengen Agreement of 14 June 1985 between the Governments of the States of the Benelux Economic Union, the Federal Republic of Germany and the French Republic on the gradual abolition of checks at their common borders). The parties of this treaty were: Belgium, Germany, France, Luxembourg and the Netherlands.

The treaty was signed in 1985 and was entered into beyond the EEC structures (but by the members of this community) and was not (at that time) a part of the community law. It was a basis to create a kind of union of many vectors or integration points. Within the framework of the accepted document there were defined the short term ones (Title $\mathrm{I}^{1}$ ) and the long term ones (Title $\mathrm{II}^{2}$ ) whose implementation was supposed to trigger the entire annihilation of the control on the borders between the parties of this treaty (Dereń, 2014).

In June 1990 there was signed a Convention from 19 June 1990 Applying the Schengen Agreement of 14 June 1985. One year afterwards the treaty was entered into by Spain and Portugal. In March 1995 the Convention came to life and the transboundary control was overruled between the parties of the very agreement. In 1997 however, the transboundary control on the frontier with Italy was suppressed ${ }^{3}$ (10.1997) and Austria $^{4}$ (12.1997) too. Within the framework of the Schengen Implementing Convention there were declared the conditions of depriving of the control on the internal borders and pointed at a range of measures which were to ensure the safety in a new situation, including the possibility to restore such a control. The freedom of movement of people was assured thanks to a record in the Article 2, p. 1 in which figured the free right to cross the internal border in any place and time without the necessity to supervise (Convention Implementing the Schengen Agreement...).

The document defined in a detailed way as follows: the rules of crossing the external border, regulations concerning the short and long term visas, precautions regulating the movement of foreigners, stay documents and inscriptions in order to deny the access, correctness in acting when to apply for the asylum, police cooperation, mutual aid in penal cases, implementing the rule of ne bis in idem, extradition, transfer of the penal sentences, regulations touching the narcotic drugs, weapons, guns and ammunition. In title IV the Schengen Informative System (SIS) was described in a detailed way, the Title comprised the regulations referring to transportation and the flow of merchandise and in the title VI there was regulated the policy of personal data protection.

The Article 2 encompassed in the analyzed document the possibility to restore the national frontier controls on the internal borders. It may happen when a country - the

${ }^{1}$ In accordance with the article 30 short term measures were supposed to be implemented on 1 st of January 1986. It should concern the following activities: introducing the common transboundary customs, visual control of the passing vehicles, conveniences in border- crossing for the people residing close to a frontier, abolishing specific control for the drivers of the traffic and within the framework of transboundary transport of goods.

${ }^{2}$ In accordance with article 30 short term measures were supposed to be brought to life on 30th of January 1990. They comprised: complete abolition of the supervision on the internal borders by transferring them to the external ones, unifying the policy of visual policy and the rules of entering the third party countries, working out the measures which are to deal with illegal immigration, unify the regulations concerning the boundary supervision and others.

${ }^{3}$ Italy signed the agreement in November 1990.

${ }^{4}$ Austria signed the agreement in April 1995. 
party of the Convention acts with regard to the public order and national safety. In such a situation one shall consult the other Parties or it may occur in a situation when there is a necessity to take up sudden actions, in this case -inform the other countries. Restoring the supervision may be implemented for a limited period of time.

A vital stage in organizing the regulation within the scope of free movement of people in the EU was implementing the Schengen Borders Code (Regulation (EC) No. 562/2006 of the European Parliament and Council from $15^{\text {th }}$ of March 2006, establishing a Community Code on the rules governing the movement of persons across borders (Schengen Borders Code)). In the years to come the resolutions of the Code were several times changed. ${ }^{5}$ At present the text in power is unanimous (Regulation (EU) 2016/399 of the European Parliament and of the Council of 9 March 2016 on a Union Code on the rules governing the movement of persons across borders (Schengen Borders Code)). It comprises basic regulations concerning the areas on which the people are to move freely. The accepted rules do not influence or undermine the right to move freely by the citizens of the EU and their family members, and the citizens of the third party countries plus their families who on the basis of separate agreements benefit from the regulations equivalent to the rights of the EU citizens.

It was concurrently pointed out that the transboundary supervision should "help to eradicate the illegal immigration and human trafficking and prevent all the threats for the internal safety, public order, public health and international relations of the member countries" (Ibidem, (6)).

Detailed regulations were placed in the very analyzed document which touch upon the possibilities of restoring control on the internal borders (art. 25-31 of the Code). However, as it had been underlined in the preamble to the Regulation, restoring the control on the frontiers should be treated as an exception. Creating an area where the free movement of people is feasible has been seen as one of the main achievements

${ }^{5}$ Alternations were implemented: Regulation (EC) No 296/2008 of the European Parliament and of the Council of 11 March 2008 amending Regulation (EC) No 562/2006 establishing a Community Code on the rules governing the movement of persons across borders (Schengen Borders Code), as regards the implementing powers conferred on the Commission OJ L 97 9.4.2008, Regulation (EC) No 81/2009 of the European Parliament and of the Council of 14 January 2009 amending Regulation (EC) No 562/2006 as regards the use of the Visa Information System (VIS) under the Schengen Borders Code OJ L 35, 4.2.2009, Regulation (EC) No 810/2009 of the European Parliament and of the Council of 13 July 2009 establishing a Community Code on Visas (Visa Code) OJ L 243, 15.9.2009 (change concerns only art. 55), Regulation (EU) No 265/2010 of the European Parliament and of the Council of 25 March 2010 amending the Convention Implementing the Schengen Agreement and Regulation (EC) No 562/2006 as regards movement of persons with a long-stay visa OJ L 85 31.3.2010 (change refers exclusively to art. 2, Accession Act from 2011, appendix V point 9), Regulation (EU) No 610/2013 of the European Parliament and of the Council of 26 June 2013 amending Regulation (EC) No 562/2006 of the European Parliament and of the Council establishing a Community Code on the rules governing the movement of persons across borders (Schengen Borders Code), the Convention implementing the Schengen Agreement, Council Regulations (EC) No 1683/95 and (EC) No 539/2001 and Regulations (EC) No 767/2008 and (EC) No 810/2009 of the European Parliament and of the Council OJ L 182 29.6.2013 (change refers exclusively to art. 1), Regulation (EU) No 1051/2013 of the European Parliament and of the Council of 22 October 2013 amending Regulation (EC) No 562/2006 in order to provide for common rules on the temporary reintroduction of border control at internal borders in exceptional circumstances OJ L 295, 6.11.2013. 
of the integration process. Due to that the suspension of this freedom shall be carried out on the basis of the rules of proportionality where the range and the time of lasting that kind of limitation is restricted to the indispensable minimum (connected with the occurrence of the reason of suspension). The introduction of such a limitation shall be seen as an ultimate measure.

A membership country has a right to restore the transboundary control in case of a serious threat for the public order and/or the internal safety. Such a control may be brought back for the period of 30 days or shorter with the possibility of prolonging it to six months, or in case of exceptional circumstances for the period of two years. In the article 26 of the analyzed document there were criteria enlisted concerning the appraisal of the occurrence of a situation which would enable restoring the control on the internal frontiers of the EU. While performing the analysis of the introduction of such a protective measure as a transboundary control one shall take into account the degree to which that kind of action will reduce the threat and also appraise the proportionality of its implementation in relation to the very threat. One needs concurrently to bear in mind the likely results of such a danger stemming from a terrorist attack or threat of their conducting as well as the consequences of introducing the protective measures for the free movement of people.

Due to the migration crisis in June 2013 there were alternations settled which concerned the possibility to bring to life a temporary control on the internal borders within the EU. On the basis of the implemented regulations the member countries obtained the chance to restore the transboundary control on the internal borders of the Schengen zone in exceptional situations connected with the threat due to shortcomings in the scope of protection of the external borders. The possibility to implement the control refers to the period of 6 months with the possibility to prolong (three times) up to 2 years (Szymańska, 2018, Regulation (EU) 2016/399, art. 29).

\section{Managing the migration crisis - in search of the efficient measures}

Integration in the "Schengen spirit" led to the alternations in the range of defining and interpreting the frontiers among the membership countries and for the entire Europe. It resulted in distinguishing in the EU two types of borders: the internal and external ones. 'Ceding the traditional functions of borders of the national countries for the external ones of the EU resulted in the augmentation of their control and protection which influenced the creation and the development of the integrated policy of management of the external borders. The transformation within this scope of cooperation impacted the other domain of cooperation (Anton, 2015).

As it was noticed by R. Skidelsky: "Inter-European migration had been an insignificant phenomenon until the moment when EU restricted itself to the countries of the Western Europe. It changed after starting the accession of the post-communist countries where low income dominated. The migration which took place afterwards cured the lack of workforce in the hosting countries, i.e. in the UK and Germany, and boosted up salaries of migrants too. However, such benefits would not have last for eternity due to the unlimited migration" (Skidelsky, 2017). By virtue of the modifications ongoing 
in the areas of the EU the migration processes have become the most considerable challenges for the EU. It is worth noticing that the membership countries which had been trying to cope with it ad hoc were taking decisions on their own. In example, on $28^{\text {th }}$ of August 2015 the German Federal Office for Migration and Refugees stated that the union regulations in the scope of asylum and migration would not be temporarily implemented so as to the citizens of Syria. It was an outcome of the prior decision which was taken upon in the context of a difficult humanitarian situation of marching migrants (with the relations of TV cameras) to the EU (Koszel, 2016, pp. 145-146). The justification of this decision was a conviction that "closing the frontier would be an introduction to the disintegration of Schengen zone and the Federal Republic of Germany as a superpower of the central Europe would bear most of the responsibility. It would mean also the surrender to the anti-European populists and demagogues and their actions to disintegrate the European Union. Apart from that withdrawing the migratory wave from Austria or Hungary back to the Balkans might have caused in less powerful countries such as Serbia, Macedonia or Montenegro some conflicts and disruptions on a great scale" (Ibidem p. 146). However, one needs to notice the fact that the described situation was understood by many immigrants as an invitation to Germany and became a kind of "reference point" in a political debate on migration in Europe. Especially the environments contradictory to immigration point out that this "invitation" could be seen as the "original sin." Such an argument came up in the Polish debate too or even publications.

A vital issue being discussed about in this context from the very beginning of the process of the intensified migration is the future of Schengen zone (Kosman, 2017, pp. 282-287, de Somer, 2017). The transformations undergoing in the surroundings of Europe, especially in the countries of the Middle East and the North Africa became an essential factor energizing the migratory movement on the southern part. Among the multitude of the immigrants residing in Europe there were surely the persons who fled the armed conflicts and repercussions as well as the ones who searched the improvement of their economic status. The hardship in division of these categories of people is one of the most vital problems which impede the reaction of the European countries (Linka, 2016, pp. 77-91).

The root causes of the intensified migration to Europe lately may be: armed conflicts (i.e. Syria or Iraq, or Afghanistan), religious persecution (i.e. the Christians from the Middle East, Yazidis), political persecutions or the ones connected with the affiliation to the defined minorities or ethnic groups and the economic reasons, mostly poverty and the lack of perspectives for the improvement. Not without a reason in this case are as well: the need for work in many countries of the EU, the policy of the European countries in this range as well as the policy of Turkey which takes advantage of the 'management of migratory waves' in realization of their own business in relations with the European Union (Jomma, 2016, pp. 99-106). One indicates more and more the changes in the climate as a reason of the migratory movements.

In the face of the 'migratory crisis' growing from 2011, the European Union took up a range of activities which were to help in this situation. Not every of the indicated proposals were finally brought to life. Part of them had a character of reactions (often ad hoc) for the particular crisis situations, part of them indicated the necessity to al- 
ter the system. The transformations concerned functioning of the Schengen zone, the European asylum system and the protection of the external frontiers of the European Union in a new situation. The proposals of changes were striving at bearing in mind either the humanitarian approach or the growing need to ensure the safety of the citizens of membership countries.

The actions concerning the reinforcement of the external borders mostly touched upon functioning of Frontex. The visible effect of the implemented changes was even the altered name for the European Border and Coast Guard Agency. In 2011 there came up a decision of augmenting the resources and founds which are at the disposal of this agency. In the years to come apart from the proposal of the Commission the significant changes in the quality of work of the Agency were not implemented. The already being realized operations like 'Triton' and 'Poseidon' were reinforced and a brand new mission EUNAVFOR Med. Sophia was triggered. Within the scope of actions run by Frontex, it was planned to launch hotspots in Greece (5) and Italy (6). In May 2015 the plan of fighting trafficking the migrants for the years 2015-2020 was accepted (The Communication from the Commission to the European Parliament, the Council, Economic and Social Committee and the Committee of Regions: EU Action Plan against migrant smuggling 2015-2020, Brussels, 27 $7^{\text {th }}$ of May 2015, COM (2015)285).

Within the framework of the actions undertaken from 2011 in the range of reforming the European asylum system there was accepted among the others, a directive touching upon the qualification of the citizens of the third parties of people without a particular country belonging as a beneficiary of the international security, unanimous status of a refugee and the scope of the rendered aid (Directive 2011/95/EU of the European Parliament and the Council of 13 December 2011 on standards for the qualification of third-country nationals or stateless persons as beneficiaries of international protection, for a uniform status for refugees or for persons eligible for subsidiary protection, and for the content of the protection granted OJ L 337/9 20.12.2011). The directive introduced among the others, the possibility to reject the protection in the situation when on a part of the territory of origin there would not arise a confirmed doubt that a particular person would be persecuted or would be harmed, or if he or she would have the access to a proper protection there (Ibidem, art. 8 p. 1). Further actions in this subject concerned the resolution called Dublin III, a directive which referred to common procedures of granting and retrieving the international protection on the areas of the EU (Directive 2013/32/EU of the European Parliament and of the Council of 26 June 2013 on common procedures for granting and withdrawing international protection OJ L 180 29.6.2013) and a directive specifying the norms of hosting the people applying to get an international protection (Regulation (EU) No 604/2013 of the European Parliament and of the Council of 26 June 2013 establishing the criteria and mechanisms for determining the Member State responsible for examining an application for international protection lodged in one of the Member States by a thirdcountry national or a stateless person, OJ L 180 from 29.6.2013).

The third area of the modifications referred to the management process of the Schengen zone. The situation which took place normalized the capability to restore the supervision on the borders, precisely on the internal borders. As J. Szymańska points out due to the actions taken by some of the countries in this domain, it had been the 
field of conflict between the Commission and its proposals to guarantee the free movement of people and some member countries (Szymańska, 2017, pp. 163-164). Eventually, having accepted the arguments of the countries the limited alternations were implemented. They concerned the implementation of a new mechanism in order to verify the usage of the legal heritage of Schengen (Council Regulation (EU) No 1053/2013 of 7 October 2013 establishing an evaluation and monitoring mechanism to verify the application of the Schengen acquis and repealing the Decision of the Executive Committee of 16 September 1998 setting up a Standing Committee on the evaluation and implementation of Schengen OJ L 295/27 6.11.2013) and establishing the rules of temporary restoring the supervision of the borders (Regulation (EU) No 1051/2013 of the European Parliament and of the Council of 22 October 2013 amending Regulation (EC) No 562/2006 in order to provide for common rules on the temporary reintroduction of border control at internal borders in exceptional circumstances, OJ L 295/1 6.11.2013). In March 2017 there were the changes in the Schengen Border Code introduced in the matter of mandatory, systematic control of all the persons who would cross the external border of the EU (including the membership citizens) (Regulation (EU) 2017/458 of the European Parliament and of the Council of 15 March 2017, amending Regulation (EU) 2016/399 as regards the reinforcement of checks against relevant databases at external borders, OJ L 74/1 18.3.2017). The migration crisis revealed the tension between the freedom of movement and the trials to limit it due to the safety issues. As it was pointed out by the commissioner D. Awramopulos "Germany, Austria, Denmark, Sweden and Norway have implemented temporary border controls starting from autumn last year owing to the influx of the migrants to the EU. The decision on keeping the control for the next three months requires the consensus of the governments of the EU countries. - Our goal is to gradually abrogate temporary border controls and bring back the quickest possible return to the normal functioning of the Schengen zone [...] Apart from the progress and the improvement of the situation, unfortunately we have not come back yet to the normal functioning of the Schengen zone" (Bartkiewicz, 2017).

In the period of the greatest intensification of the migratory issues in Europe, the European Committee presented the proposals of the actions in shape of the European program in the range of migration (Communication from the Commission to the European Parliament, the Council, the European Economic and Social Committee and the Committee of the Regions: A European Agenda on Migration (2015), COM (2015) 240, 13 May 2015). Among the four domains of action one could find: the reform of the Dublin system, reinforcing the management of the external borders and saving migrants on the sea, limiting the encouragements to migrate to Europe and unconnected directly with the crisis situation, the proposal to correlate the migratory policy to Europe with the needs of the European labor market. Issued in the years to come by the EU Commission proposals of detailed solutions have not met the comprehension of the member countries. As J. Szymanska points out: "Finding the compromise between various visions of the reform of the Dublin system turned out to be exceptionally difficult. The current course of the debate revealed a tendency to deepen the divisions between the membership countries on this field. The debate itself on the asylum notions transformed at times in the festival of mutual threats and accusations (among the 
others in the discussion over the perspective of the sanctions for not granting the access to refugees within the framework of the relocation program)" (Szymańska, 2017, p. 169). The most controversial, from this very point of view, was the proposal of relocation and displacing the refugees who arrived to Europe. In the original version one assumed the mandatory quantity division between the membership countries calculated on the basis of the number of citizens of the hosting country, their GDP and the rate of unemployment. This proposal met a disapproval from the Visegrad Group. One needs to admit that Poland unanimously joined this objection after the alternation in the authority and calling upon the government of B. Szydlo. The previous coalition of PO-PSL were trying to avoid clear declarations and position. One of the reasons why such actions were run in Poland in 2015 was the election campaign during which the topic of migration was one of the main points of the political dispute. One needs to remark that nevertheless the definite opposition of the Visegrad Group the government of E. Kopacz declared the participation in the relocation of refugees.

\section{Implementing the means of control in the opinion of the Poles}

In the political debate and the media commentaries (especially in the Internet comments) the phenomenon of the 'migration crisis' is often connected with the increase of the threat of the terrorist attacks (Marcinkowski, 2017, pp. 117-131). It influences without a shadow of doubt the feeling of security of the European citizens and their acceptance for the actions of the country or the EU itself in the very situation. Poland is also the case which (fortunately) has not been touched directly by the dramatic events. However, the media coverage reinforces the general conviction of a growing threat. Among the actions which are proposed by the politicians in this situation is a possibility to introduce a transboundary control (on the internal borders of the EU).

The problematics of acceptance for the implementation of the intensified controls on the airports, frontiers and railway stations is a subject of cyclical research run by CBOS (the Center of Research on the Public Opinion). Nevertheless, one is required to draw attention to that fact that the question on such activities of the country is asked to respondents in the context of the threat of terrorism which may not be left without an impact for the received answers. Even taking into account this context, one needs to remark that the amount of the people accepting the intensified supervision of the borders is enormous. In December 2015 the quantity of the researched accepting such actions taken in order to increase the safety was the highest and numbered to $94 \%$ (Zagrożenie terroryzmem, 2016).

Simultaneously, in the same research a majority of the questioned accepted the exacerbated migratory regulations to ensure safety. In December 2015 this value was one of the highest of the measured ones and amounted to $82 \%$ of the positive answers. It indicates unanimous recognition of migration as a threat by the majority of the researched ones. It is also visible in some other research realized by CBOS and referring to the attitudes of the Poles towards accepting the refugees. In the research run in June 2018 the question whether to host the refugees coming to Europe, $72 \%$ responded negatively (46\% definitely not; $26 \%$ rather not) (Stosunek, 2018). The media and po- 
litical statements connecting the terrorist attacks with the migratory crisis undoubtedly reinforce the feeling of threat and determine in a crucial way social points of view towards the actions of a country in this scope.

\section{Diagram 1. Would you for your own safety agree on the intensified controls at the frontiers, airports, railway stations? - positive answers}

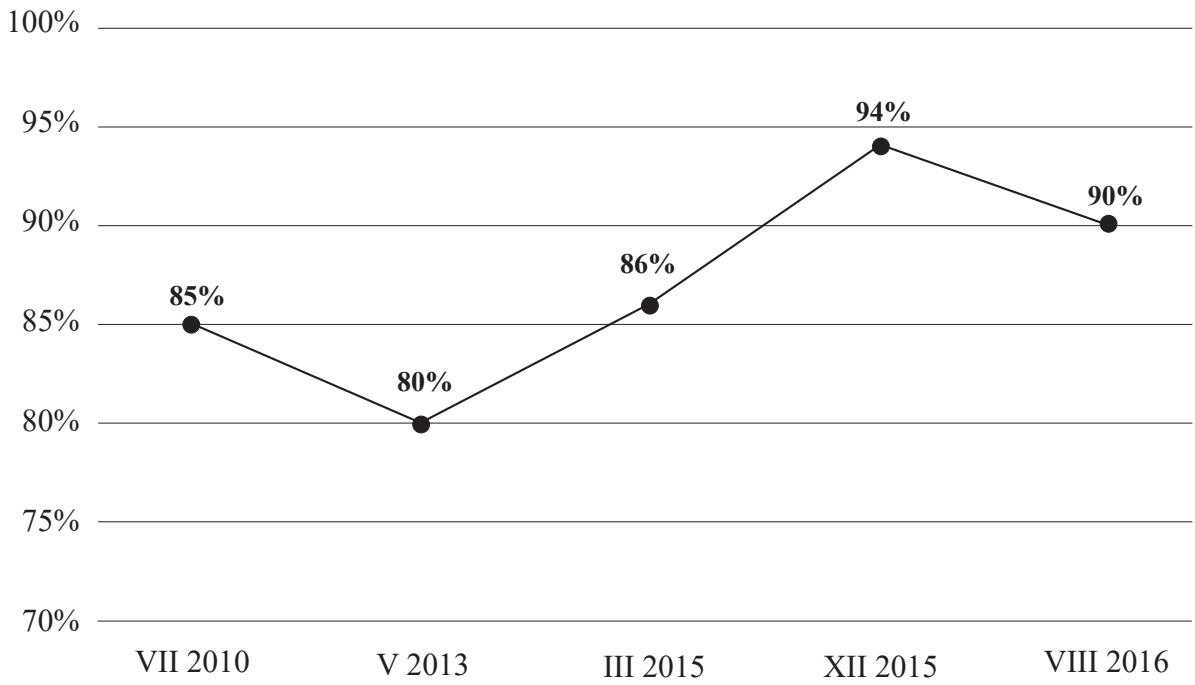

Source: Zagrożenie terroryzmem, 2016.

Diagram 2. Would you for your own safety agree on the reinforcement of the migratory regulations? - positive answers

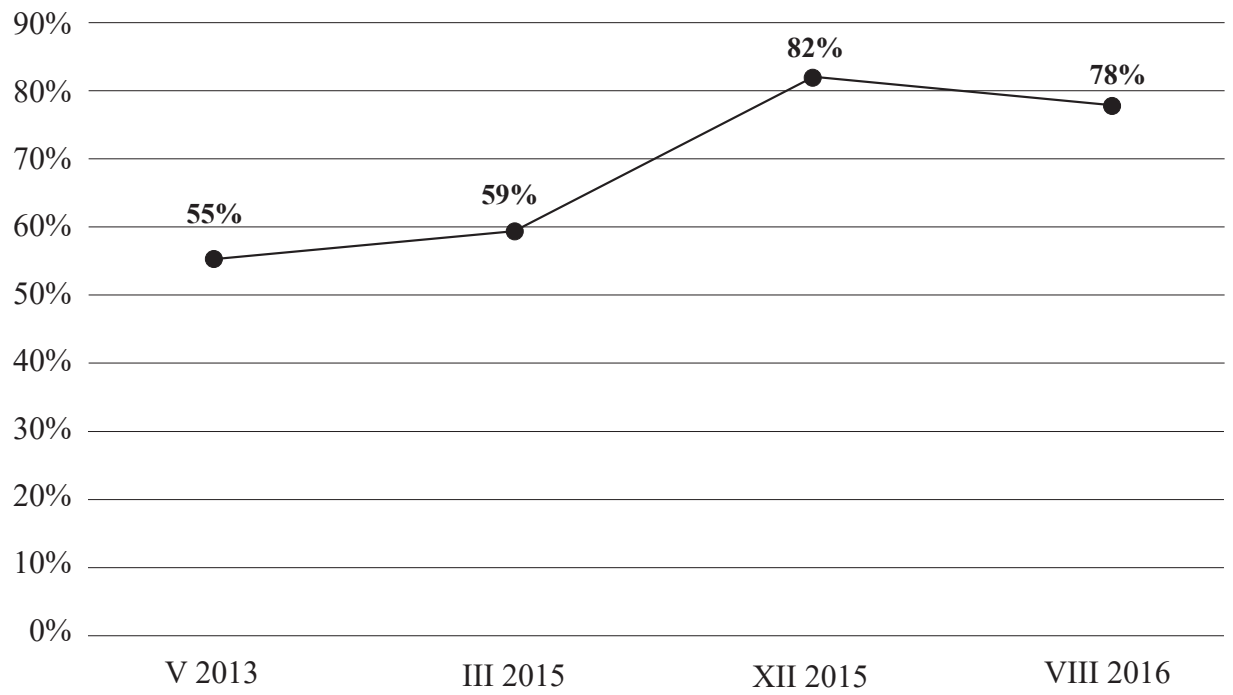

Source: Zagrożenie terroryzmem, 2016. 


\section{Citizens of the Polish and German frontier and the supervision of the borders}

The problem concerning passing a border and free movement or its lack when crossing it is extremely vital for the inhabitants of frontier areas. Real social processes have created for last years connections beyond the existing country border. The opportunity to work, live or use the services at the neighboring side became common for the people living in these areas. An interesting example investigated at the Polish-German frontier terrains. Concurrently, the social processes described hereinabove became also a factor determining social attitudes on the very described surface.

In April 2016 on the Polish and German frontier area there were conducted social researches which touched upon the problems of the attitudes of the citizens towards bringing back the frontier supervision. The sociological research entitled "Migracje w Europie a poczucie bezpieczeństwa mieszkańców terenów przygranicznych województwa lubuskiego" ("Migration in Europe and the feeling of safety of the citizens of borderline areas of Lubuskie voivodship") were realized by the Zachodni Ośrodek Badan Społecznych i Ekonomicznych on behalf of the Lubuski Voivodship Office. The report from the research was elaborated by: Marek Rusakiewicz, Jarosław Urbański and Tomasz Marcinkowski. The research encompassed adult citizens of three frontier localities: Słubice, Kostrzyn nad Odrą and Łęknica. The research was conducted with the participation of adults from each of the cited location: in Kostrzyn nad Odrą $-\mathrm{N}=299$, in Słubice $-\mathrm{N}=299$ and in Łęknica $-\mathrm{N}=303$. Altogether, there were 901 interviews carried out with the use of the direct method - "face to face" (PAPI)

One of the questions which were posed to the respondents during this research referred to the matter whether in their opinion Poland should introduce the supervision of the borders (on the internal borders of the EU). Over $60 \%$ of the researched shared a positive opinion on this issue $62.9 \%$ (43.9\% definitely yes, $19 \%$ rather yes). Every third respondent was of a contradictory opinion $32.5 \%$ (18.6\% definitely no, $13.9 \%$ rather no). The ones who were usually in favor of the implementation of the supervision of the borders $-68 \%$ ( $48 \%$ definitely yes, $20 \%$ rather yes), the questioned from the youngest group $18-34$ years of age $73.8 \%$ (54\% definitely yes, $19.8 \%$ rather yes) and the citizens of Kostrzyn by the Odra River (55.6\% definitely yes, $17.3 \%$ rather yes). A contradictory opinion more often was expressed by the other researched ones at the age of $35-5440.8 \%$ (24.9\% definitely no, $15.9 \%$ rather no), persons with higher education $39 \%$ (22.1\% definitely no, $16.9 \%$ rather no) and the citizens of Łęknica $42.5 \%$ ( $22.5 \%$ definitely no, $20.9 \%$ rather no). The detailed results have been illustrated in the diagrams herein below:

${ }^{6}$ For each of the researched localizations the surveys were representative so as to the sex and age of the questioned. The choice of the sample was based on the date from GUS (Central Statistical Office). The mistake of the appraisal totally amounted to $3.26 \%$ with the assumed level of trustfulness on the level of 0.95 . However in every single location it amounted to $5.66 \%$. The research was carried out from 11 to $15^{\text {th }}$ of April 2016. 


\section{Diagram 3. Poland should implement the supervision of the borders}

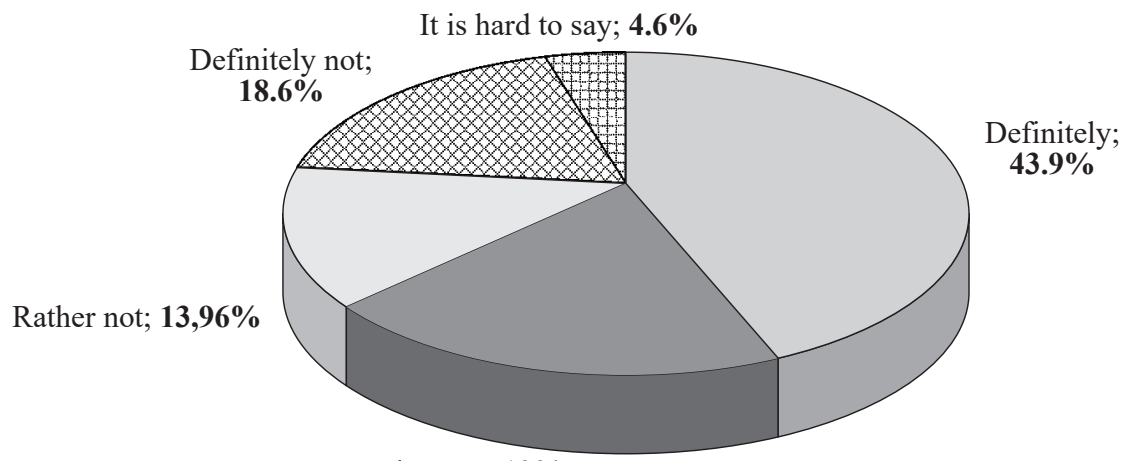

Rether yes; $\mathbf{1 9 \%}$

Source: Report "Migracje w Europie a poczucie bezpieczeństwa mieszkańców terenów przygranicznych województwa lubuskiego", Zachodni Ośrodek Badań Społecznych i Ekonomicznych, Gorzów Wielkopolski 2016 (Report "Migration in Europe and the feeling of safety of the citizens of frontier locations of Lubuskie Voivodship', Western Center of Social and Economic Research, Gorzów Wielkopolski 2016) (in the collections of the author)

\section{Diagram 4. Poland should implement the supervision of the borders}

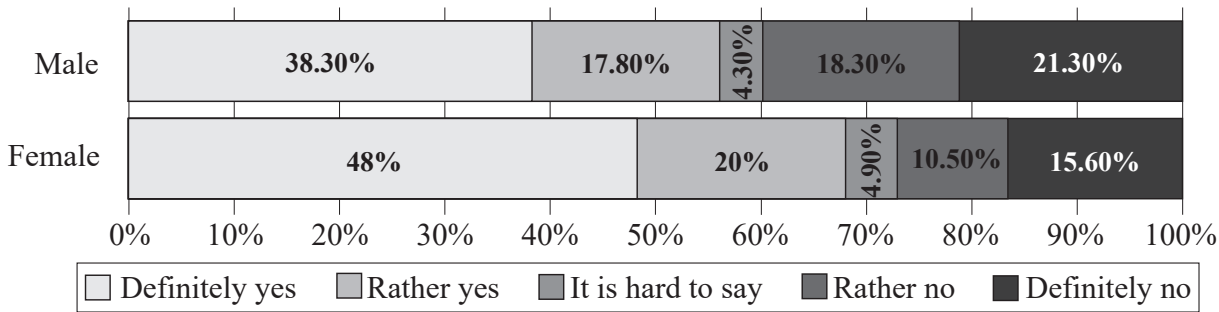

Source: Report "Migracje w Europie a poczucie bezpieczeństwa mieszkańców terenów przygranicznych województwa lubuskiego", Zachodni Ośrodek Badań Społecznych i Ekonomicznych, Gorzów Wielkopolski 2016.

Diagram 5. Poland should implement the supervision of the borders

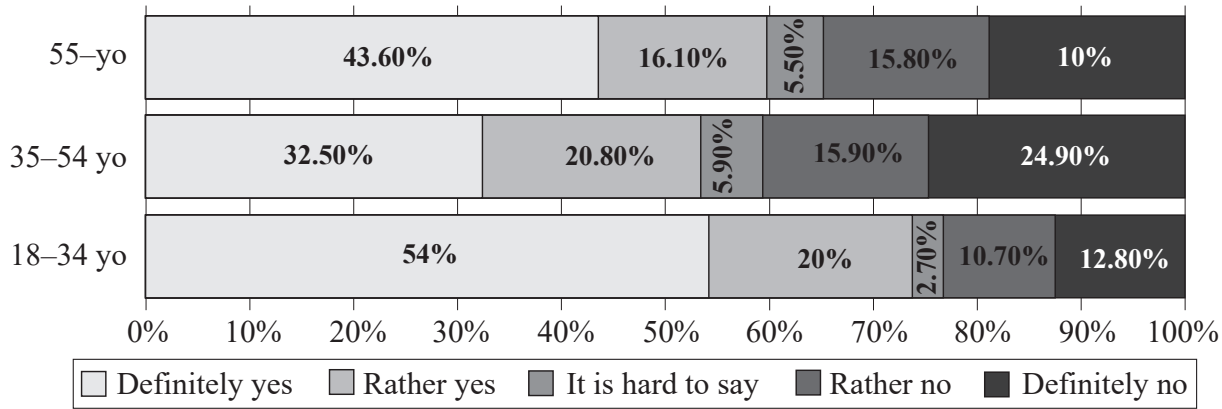

Source: Report "Migracje w Europie a poczucie bezpieczeństwa mieszkańców terenów przygranicznych województwa lubuskiego", Zachodni Ośrodek Badań Społecznych i Ekonomicznych, Gorzów Wielkopolski 2016. 


\section{Diagram 6. Poland should implement the supervision of the borders}

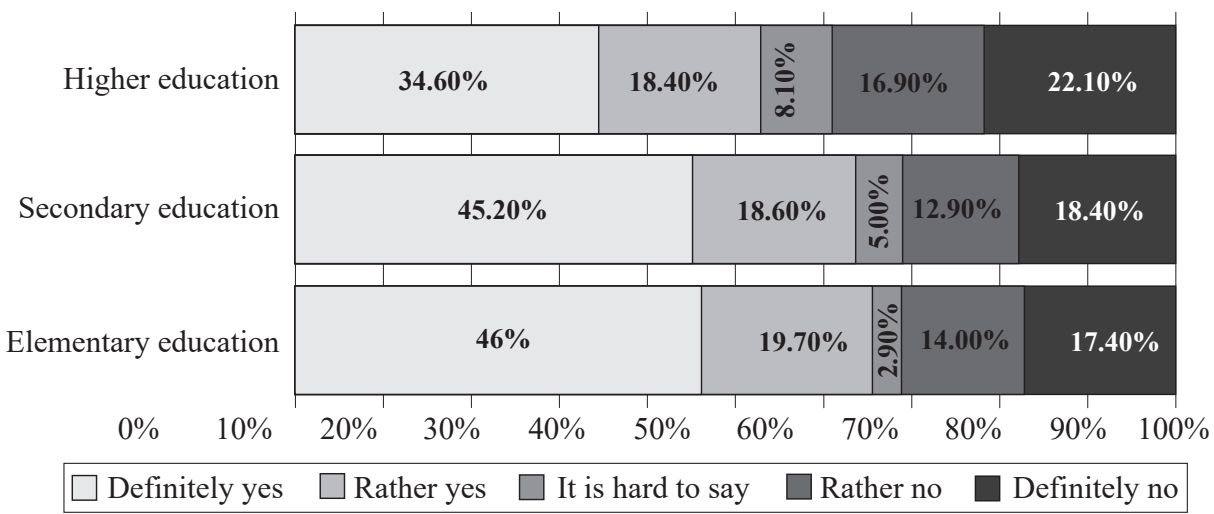

Source: Report "Migracje w Europie a poczucie bezpieczeństwa mieszkańców terenów przygranicznych województwa lubuskiego", Zachodni Ośrodek Badań Społecznych i Ekonomicznych, Gorzów Wielkopolski 2016.

\section{Diagram 7. Poland should implement supervision of the borders}

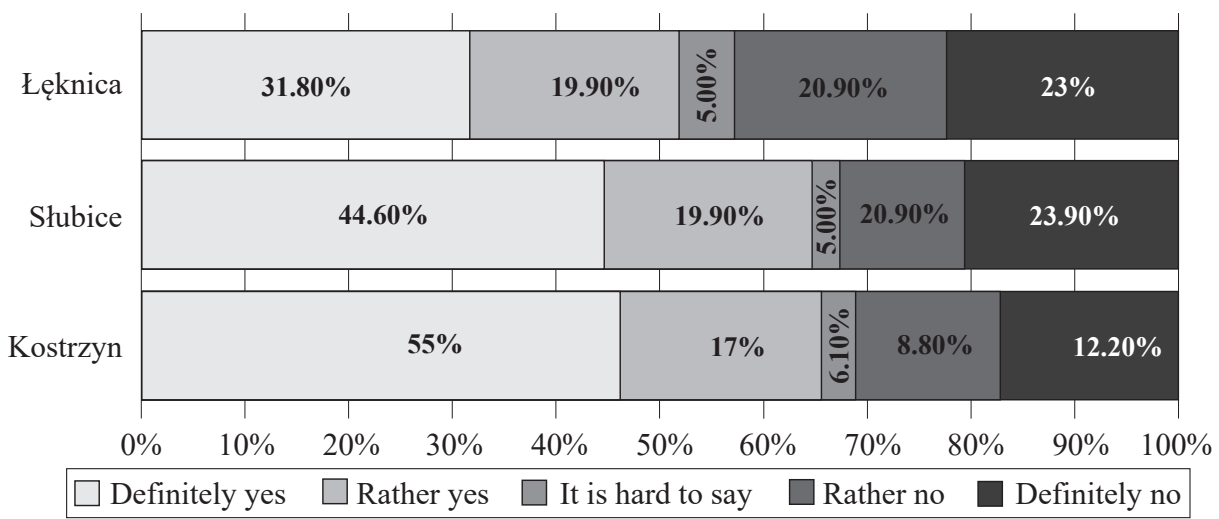

Source: Report "Migracje w Europie a poczucie bezpieczeństwa mieszkańców terenów przygranicznych województwa lubuskiego", Zachodni Ośrodek Badań Społecznych i Ekonomicznych, Gorzów Wielkopolski 2016.

It may seem that despite everyday practice of the social life at the frontier and experiences connected with that for many of the researched citizens of the mentioned localizations, the possibility to introduce the control on the borders where they live in the close neighborhood is acceptable. The feeling of threat evoked by the media campaign on the topic of the 'migration crisis' created a situation of the approval to introduce the solutions which may impede the life of many citizens every day (Marcinkowski, 2017, pp. 117-131). The factor which determines the approval for such impediment is the lowered feeling of safety.

If one however was to try to compare the results of the research realized by ZOBSiE (Zachodni Ośrodek Badań Społecznych i Ekonomicznych) on the Polish and Ger- 
man border with the results of the Centre of Research of the Public Opinion which were realized in the similar period of time, one could observe the essential differences in case of the analyzed notions. Nevertheless, one needs to bear in mind the limitations of such a comparison connected with a different range of the research (national versus local ones), the other research problematics (the terrorist context versus the migratory one). Taking even into account this stipulation it is well worth noticing the difference in the answer for the question of the possibility to supervise the frontiers. The difference does not concern the set of the answers because in the first and in the second case the positive answers dominate. However, the amount of the people who accept the implementation of the frontier control among the persons who reside the closest is the lowest than on the national trial. The positive answers in the investigated three localities of the frontier indicated $63 \%$ and in the national ones $90 \%$. Every third researched person $(33 \%)$ on the Polish and German frontier expressed a negative opinion in the analyzed domain, but in the national trial the amount of such answers were $6 \%$.

\section{Summary}

Freedom of movement from the very beginning was one of the most vital achievements of the process of the European integration. It required limiting and reforming the activity from the countries side and it referred to the scope of activity in the range of the frontier of a country. It introduced as well the alternation in the recognition of the frontier itself via the differentiation for the internal and external borders in the EU. The membership countries however from the very start stipulated that in the situation of a crisis there remains a possibility to bring back the border control. The discussion over the feasibility and the scope of the implementation of these activities came up in connection to the so called migration crisis in Europe.

The Poles could experience in the times of communism the difficulties connected with the possibility to cross the borders. This situation has changed thanks to the accession to the EU and the opportunity to benefit from the right of Schengen zone. This relatively recently gained freedom has been impacted by a new migratory reality in Europe. In the face of a conflict of freedom and safety which arose due to the so called migration conflict also in Poland there came up a discussion of restoring the control at the frontiers of a country within the EU. As national research of CBOS (Center of the Research of Public Opinion) reveal such solution was accepted in December 2015 by $90 \%$ of the respondents.

Freedom of crossing the borders is also a daily experience of the dwellers of the terrains by the frontiers. Such possibility of crossing the borders 'as if they were not present' became a dominating factor which would determine the development of the transboundary relations in the economic, social and human (personal) scope. As the survey conducted by the Zachodni Ośrodek Badań Społecznych i Ekonomicznych showed among the citizens of the three transboundary localities also here there is the acceptance of restoring the frontiers present. However the degree of the acceptance is considerably lower here $(62.9 \%)$. Concurrently, one needs to point out that every third researched person there is against such changes. The closeness of the potential threat (migrants by the other side of the border) does not enhance restricting the attitudes 
connected with doubts and the feeling of threat which may trigger the support for the control at the border. On the contrary, daily routine provokes that at least a part of the researched (about 33\%) is against limiting the free movement of the people.

\section{Bibliography}

Adamczyk A. (2017), Kryzys migracyjny w Europie a polska polityka migracyjna, „Studia Migracyjne - Przegląd Polonijny", z. 1(163).

Antoń P. (2015), Symboliczne zanikanie granic w Europie. Strefa Schengen - konsekwencje zmiany koncepcji granic w Unii Europejskiej, „Konteksty społeczne”, tom 3, nr 2 (6).

Bartkiewicz A. (2017), UE: Strefa Schengen wciąz z kontrolami na granicach, „Rzeczpospolita” 25.01.2017, http://www.rp.pl/Unia-Europejska/170129363-UE-Strefa-Schengen-wciaz-zkontrolami-na-granicach.html.

Communication from the Commission to the European Parliament, the Council, Economic and Social Committee and the Committee of Regions: EU Action Plan against migrant smuggling 2015-2020, Brussels, $27^{\text {th }}$ of May 2015, COM (2015)285.

Communication from the Commission to the European Parliament, the Council, the European Economic and Social Committee and the Committee of the Regions: A European Agenda on Migration (2015), COM (2015) 240, 13 May 2015.

Convention Implementing the Schengen Agreement between the Governments of the States of the Benelux Economic Union, the Federal Republic of Germany and the French Republic on the gradual abolition of checks at their common borders, OJ L 239 22.9.2000

Council Regulation (EU) No 1053/2013 of 7 October 2013 establishing an evaluation and monitoring mechanism to verify the application of the Schengen acquis and repealing the Decision of the Executive Committee of 16 September 1998 setting up a Standing Committee on the evaluation and implementation of Schengen, OJ L 295/27 6.11.2013.

Cucurescu V., Amaral C. E. P., Gabrichidze G., Horga I., Kruglashov A., Latoszek E., Pachocka M. (red.) (2018), The European Union and the Eastern Partnership: Security Chellenges, ECSA Moldova, Chisinau-Cernauti-Tbilisi.

Czachór Z. (2013), Kryzys i zaburzona dynamika Unii Europejskiej, Warszawa.

Czachór Z., Marcinkowski T. (red.) (2017), Polska - Niemcy - Unia Europejska. Razem czy osobno?, Warszawa.

Dereń K. (2014), Rozwój strefy Schengen, http://www.psz.p1/120-unia-europejska/rozwoj-strefyschengen.

Directive 2011/95/EU of the European Parliament and the Council of 13 December 2011 on standards for the qualification of third-country nationals or stateless persons as beneficiaries of international protection, for a uniform status for refugees or for persons eligible for subsidiary protection, and for the content of the protection granted, OJ L 337/9, 20.12.2011.

Directive 2013/32/EU of the European Parliament and of the Council of 26 June 2013 on common procedures for granting and withdrawing international protection, OJ L 180, 29.6.2013.

Dragan A. (2015), System informacyjny Schengen drugiej generacji jako nowoczesne rozwiazanie informatyczne, „Annales Universitatis Mariae Curie-Skłodowska”, Sectio G, vol. LXII, I, Lublin

Europa bez granic. Strefa Schengen, https://ec.europa.eu/home-affairs/sites/homeaffairs/files/elibrary/ docs/schengen_brochure/schengen_brochure_dr3111126_pl.pdf.

Grochalski S. M. (2015), Swoboda przemieszczania się i pobytu jako podstawowe prawo w wymiarze przedmiotowym obywatela UE, w: Integracja europejska. Gtówne obszary badawcze, red. K. A. Wojtaszczyk, J. Tymanowski, P. Stawarz, Warszawa. 
Jomma F. (2016), Społeczno-ekonomiczne i polityczne przyczyny uchodźctwa do Europy na przykładzie wybranych państw Bliskiego Wschodu, w: Polska i Europa wobec kryzysu imigracyjnego. W poszukiwaniu złotego środka, red. F. Jomma, A. Linka, Szczecin.

Jomma F., Linka A. (red.) (2016), Polska i Europa wobec kryzysu imigracyjnego. W poszukiwaniu złotego środka, Szczecin.

Kissinger H. (2017), Porzadek światowy, Wołowiec.

Konwencja Wykonawcza do Układu z Schengen z dnia 14 czerwca 1985 roku (2000), Dz. U. UE L. 239/19 z 22 września 2000 roku.

Kosman M. M. (2017), Kryzys imigracyjny w UE w latach 2015-2017. Aspekty prawne i polityczne, „Rocznik Integracji Europejskiej” nr 11.

Koszel B. (2016), Unia Europejska, Niemcy, problem uchodźców (2014-2016), „Rocznik Integracji Europejskiej" nr 10.

Lesiewicz E. (2016), Strefa Schengen w dobie kryzysu migracyjnego, „Przegląd Politologiczny” nr 4.

Linka A. (2016), Kim jest uchodźca? - otwarte pytanie kryzysu migracyjnego, w: Polska i Europa wobec kryzysu imigracyjnego. W poszukiwaniu złotego środka, red. F. Jomma, A. Linka, Szczecin.

Marcinkowski T. (2017), Kryzys migracyjny a poczucie bezpieczeństwa. Polska, Niemcy, pogranicze polsko-niemieckie, w: Polska, Niemcy, Unia Europejska. Razem czy osobno?, red. Z. Czachór, T. Marcinkowski, Warszawa.

Oczekiwania pod adresem polskich polityków w związku z kryzysem migracyjnym w UE (2017), Komunikat z badań nr 65/2017, Centrum Badania Opinii Społecznej, Warszawa, maj 2017.

Pachocka M., Visvizi A. (2018), Rethinking the Twin migration and Refugee Crises in Europe through the Lens of Safety and Security, w: The European Union and the Eastern Partnership: Security Chellenges, red. V. Cucurescu, C. E. P. Amaral, G. Gabrichidze, I. Horga, A. Kruglashov, E. Latoszek, M. Pachocka, ECSA Moldova, Chisinau-Cernauti-Tbilisi.

Raport „Migracje w Europie a poczucie bezpieczeństwa mieszkańców terenów przygranicznych województwa lubuskiego” (2016), Zachodni Ośrodek Badań Społecznych i Ekonomicznych, Gorzów Wielkopolski.

Regulation (EC) No. 562/2006 of the European Parliament and Council from 15 th of March 2006, establishing a Community Code on the rules governing the movement of persons across borders (Schengen Borders Code), OJ L 105, 13.4.2006.

Regulation (EU) 2016/399 of the European Parliament and of the Council of 9 March 2016 on a Union Code on the rules governing the movement of persons across borders (Schengen Borders Code), OJ L 77, 23.3.2016.

Regulation (EU) 2017/458 of the European Parliament and of the Council of 15 March 2017, amending Regulation (EU) 2016/399 as regards the reinforcement of checks against relevant databases at external borders, OJ L 74/1 18.3.2017.

Regulation (EU) No 1051/2013 of the European Parliament and of the Council of 22 October 2013 amending Regulation (EC) No 562/2006 in order to provide for common rules on the temporary reintroduction of border control at internal borders in exceptional circumstances, OJ L 295/1 6.11.2013.

Regulation (EU) No 604/2013 of the European Parliament and of the Council of 26 June 2013 establishing the criteria and mechanisms for determining the Member State responsible for examining an application for international protection lodged in one of the Member States by a third-country national or a stateless person, OJ L 180, 29.6.2013.

Ruszkowski J., Podgórzańska R. (red.) (2017), Państwo w Unii Europejskiej, Szczecin.

Skidelsky R. (2017), Unia nie jest gotowa na niekontrolowany przepływ ludzi, http://krytykapolityczna.pl/swiat/ue/skidelsky-migracja-brexit. 
Somer de M., Preserving or Strengthening Schengen? (2017), European Policy Centre, Commentary, 10 November 2017, http://www.epc.eu/pub_details.php?cat_id=4\&pub_id=8055.

Stosunek Polaków i Czechów do przyjmowania Uchodźców (2018), Komunikat z badań nr 87/2018 CBOS, Warszawa, lipiec 2018.

Szymańska J. (2017), Strategia Unii Europejskiej wobec kryzysu migracyjnego: priorytety, bariery, efekty, ,Studia BAS”, nr 3 (51).

Szymańska J. (2018), Kontrole na granicach wewnętrznych strefy Schengen: wyjątki staja się reguła, „Biuletyn PISM”, nr 17 (1590).

Trojanowska-Strzęboszewska M. (2011), Trzy oblicza unijnych granic. Polityka granic zewnętrznych Unii Europejskiej, Warszawa.

Wojtaszczyk K. A., Tymanowski J., Stawarz P. (red.) (2015), Integracja europejska. Główne obszary badawcze, Warszawa.

Zagrożenie terroryzmem (2016), Komunikat z badań nr 127/2016, CBOS, Warszawa wrzesień 2016.

\section{Summary}

Freedom of movement is one of the basic achievements and effects of the European integration process. Benefiting from this freedom has become an important experience for millions of the Europeans. Crisis phenomena, mainly related to the migration breakdown, revealed institutional and legal problems and had an impact on public opinion. The sense of threat and political and organizational difficulties led to the decision to reinstate control on the internal borders in many places in the EU. As it appears from nationwide surveys, there is also acceptance in Poland of such activities. Research conducted on the Polish-German borderland indicates that also the inhabitants of these areas support such decisions, but the degree of acceptance of the restoration of border control is lower here than in national surveys.

Key words: migration crisis, border control, European integration, Schengen, security

\section{Kryzys migracyjny a kontrola granic wewnątrz Unii Europejskiej}

\section{Streszczenie}

Swoboda przemieszczania się jest jednym z podstawowych osiągnięć oraz efektów procesu integracji europejskiej. Korzystanie z tej wolności stało się ważnym doświadczeniem milionów Europejczyków. Zjawiska kryzysowe, związane przede wszystkim z kryzysem migracyjnym ukazały problemy instytucjonalno-prawne oraz miały wpływ na opinię publiczną. Poczucie zagrożenia i trudności polityczne i organizacyjne doprowadziły do decyzji o przywróceniu kontroli na wewnętrznych granicach $w$ wielu miejscach UE. Jak wynika $\mathrm{z}$ badań ogólnopolskich, także w naszym kraju jest akceptacja takich działań. Badania przeprowadzone na pograniczu polskoniemieckim wskazują, że także mieszkańcy tych terenów popierają takie decyzje, jednak stopień akceptacji przywracania kontroli granicznych jest tu mniejszy niż w badaniach ogólnopolskich.

Słowa kluczowe: kryzys migracyjny, kontrola graniczna, integracja europejska, Schengen, bezpieczeństwo 